\title{
A resolução dos conflitos previdenciários no Brasil e os desafios do acesso à justiça: uma análise comparativa dos sistemas de justiça administrativa dos países da common law ${ }^{1}$
}

\section{Social security litigation in Brazil and the challenges of access to justice: a comparative analysis of the administrative justice system in the common law countries}

Alexandre da Silva Arruda ${ }^{2}$

\section{RESUMO:}

O artigo analisa comparativamente o sistema de resolução de conflitos previdenciários nos países mais representativos da common law e o modelo brasileiro. O texto argumenta que as cortes federais brasileiras estão sobrecarregadas em razão da crescente quantidade de conflitos envolvendo a concessão de benefícios previdenciários, gerando acúmulo de processos e demora nos julgamentos. Dentro de uma perspectiva funcional, a análise comparativa busca compreender como os países da common law estudados asseguram o acesso à justiça aos reclamantes nos conflitos previdenciários. $\mathrm{O}$ artigo sugere que o problema do modelo brasileiro pode estar relacionado à falta de independência do Conselho de Recursos da Previdência Social e à ausência de garantias que assegurem o devido processo legal na fase de revisão administrativa, levando os juízes a empreenderem um controle judicial com reduzido grau de deferência, o que, por sua vez, estimula a judicialização dos conflitos.Com base na análise comparativa realizada, o artigo propõe um meio alternativo para a resolução destas disputas no Brasil, com o objetivo de proporcionar um maior acesso à justiça e reduzir a judicialização dos conflitos previdenciários.

\section{PALAVRAS-CHAVE:}

Acesso à justiça. Análise Comparativa. Conflitos previdenciários. Common law.Adjudicação administrativa.Deferência judicial.

\footnotetext{
ABSTRACT:

1. Gostaria de agradecer à professora Mariana Prado, Associate Dean (GraduateSudies)da Faculdade de Direito da Universidade de Toronto, pela orientação prestada durante a elaboração deste artigo.

2 Vínculo Institucional: Juiz Federal, Visiting Researcher na University of Toronto - Faculty of Law, Doutorando em Justiça Administrativa na Universidade Federal Fluminense.

Endereço: 17 Powerhouse St. unit 19 Toronto, Ontario. Canada. ZIP Code: M6H 0C5.

Telefone: +1(416) 831-4993 e +55(21) 99897-2663 (WhatsApp) Email: alexandresarruda@ hotmail.com
} 
The article develops a comparative analysis of the social security disputes resolution system in representative common law countries and the Brazilian system. The main argument is that Brazilian federal courts are overburdened by the growing number of conflicts involving social security benefits, causing backlog and long delays. Taking a functional approach, the analysis examines how the common law countries studied ensure access to justice for claimants in a social security dispute. The article suggests that the problem in Brazil may be related to the lack of independence of the Brazilian Social Security's Appeals Council and to the lack of procedural fairness in the administrative reconsideration phase, leading the courts to engage in aggressive judicial review with low levels of deference, which in turn encourages claimants to go to the courts.Based on this comparative analysis, the article suggests an alternative way to resolve these disputes in Brazil, with the purpose of granting more access to justice and reducing the judicialization of social security disputes.

\section{KEYWORDS:}

Access to Justice. Comparative Analysis. Social Security disputes. Common Law. AdministrativeAdjudication. Judicial Deference.

\section{Introdução}

A proliferação de normas destinadas a melhorar as condições econômicas e sociais das populações menos favorecidas é uma das principais características do Estado do bem-estar social. Entretanto, para que esse objetivo seja alcançado se faz necessária a existência de instituições que possam implementar os direitos sociais e resolver os conflitos daí decorrentes, o que levanta questões relacionadas ao acesso à justiça. ${ }^{3}$

Nos países da common law, foram criados tribunais administrativos para a resolução das disputas decorrentes da implementação da nova legislação social e econômica do Estado do bem-estar. Isto porque os custos de utilização do aparato judicial seriam desproporcionais aos valores envolvidos e a quantidade potencial de disputas iria sobrecarregar as cortes ${ }^{4}$. Segundo Street (1981, p. 298-304), "the Welfare State has another relevant manifestation. It institutes machinery to protect the weak individual against the Strong - to interfere with the ordinary play of Market forces and these institutions are often administrative tribunals.

No Brasil, o Estado do bem-estar social, que foi criado na década de 1930 e se expandiu a partir da Constituição de 1988,também trouxe desafios relacionados ao

\footnotetext{
${ }^{3}$ CAPPELLETTI, Mauro; GARTH, Bryant. Access to Justice and the Welfare State. Cappelletti, Mauro (Coord.). Florença: Le Monnier, 1981. p. 20-21.

${ }^{4}$ CRAIG, Paul. Administrative Law, 5 ed .Londres: Sweet\& Maxwell, 2003. p. 6.
} 
acesso à justiça. A crescente busca pela implementação dos direitos sociais gerou o desenvolvimento de mecanismos e instituições para viabilizar o acesso a esses direitos quando negados pelo Estado, tais como a assistência judiciária gratuita, as ações coletivas para proteção de interesses difusos e o os meios alternativos de resolução de disputas. ${ }^{5}$ As exigências cada vez maiores de cumprimento dos compromissos do Estado do bem-estar social fizeram com que o Poder Judiciário exercitasse um controle judicial da Administração Pública com baixo grau de deferência, promovendo diretamente os direitos sociais previstos na Constituição. ${ }^{6}$

Contudo, o modelo brasileiro de implementação dos direitos sociais pelo Poder Judiciário parece ter chegado a um ponto de exaustão. As estatísticas revelam que as cortes de justiça ${ }^{7}$ estão congestionadas com esses casos. Entre 2014 e 2016,foram ajuizados cerca de 3,5milhões de novos processos na primeira instância do Poder Judiciário brasileiro envolvendo a concessão de benefícios previdenciários. ${ }^{8}$ Em consequência do acúmulo de casos, os direitos postulados nestas ações somente são implementados, em caso de vitória, após uma longa espera. Com efeito, o tempo médio de duração dos processos na Justiça Federal brasileira é superior a 7 anos. ${ }^{9}$

O sistema judicial brasileiro depara-se com o que Cappelletti (1993, p. 287) denominou de obstáculo procedimental ao acesso à justiça, que ocorre quando a solução normal dos conflitos - a litigância contenciosa nas cortes de justiça -já não representa a melhor maneira de proporcionar a efetiva reivindicação de certos direitos. Neste cenário, a busca pelo acesso à justiça deve se dar através de alternativas reais às cortes ordinárias e ao procedimento usual de litigância.

\footnotetext{
${ }^{5}$ Essas reformas institucionais coincidem com as três "ondas" do movimento de acesso à justiça identificadas por Mauro Cappelletti nos Estados Unidos (GARTH, Bryant; CAPPELLETTI, Mauro. Access to Justice: The Newest Wave in the Worldwide Movement to Make Rights Effective. Buffalo Law Review, v. 27, n. 2, p. 181-292, 1978)

${ }^{6}$ BRITO, Thiago Carlos de Souza. Fundamentação das Decisões Judiciais: Elementos para Superação do Conceito de Motivação das Decisões a partir da Análise Comparativa da Atuação Jurisdicional da Supreme Courte dos Tribunais Brasileiros. Tese de Doutorado. p. 81

${ }^{7}$ Neste artigo reservo a expressão "cortes" para os órgãos integrantes do Poder Judiciário e "tribunais" para os órgãos administrativos envolvidos na adjudicação dos conflitos entre cidadãos e o governo, a fim de utilizar a mesma nomenclatura empregada nos países da common law estudados.

8 Dados obtidos nos Painéis do Conselho Nacional de Justiça. Disponíveis em https://paineis.cnj.jus.br/QvAJAXZfc/opendoc.htm?document=qvw_1\%5Cpainelcnj.qvw\&host=QVS\%40 neodimio03\&anonymous=true, acesso em 17/05/2018.

${ }^{9}$ Dados extraídos da comparação entre os Relatórios Justiça em Números do Conselho Nacional de Justiça, edições 2015 e 2017, disponíveis em http://www.cnj.jus.br/programas-e-acoes/pj-justica-emnumeros, acesso em 01/03/2018.
} 
Neste ponto, é importante ressaltar que acesso à justiça tem um significado muito mais amplo do que possibilidade de ingressar com uma ação judicial. $\mathrm{O}$ acesso à justiça abrange os mecanismos e instituições para resolver as disputas nas sociedades modernas, a fim de tornar efetivos os direitos das pessoas que não têm acesso a uma

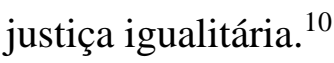

E é dentro da perspectiva da chamada" terceira onda" do movimento de acesso à justiça que este artigo buscará analisar um meio alternativo para a resolução dos conflitos entre o cidadão e a Administração Pública no Brasil, em especial daqueles envolvendo prestações previdenciárias, de modo a assegurar a composição justa destes litígios e a redução da judicialização.

A análise comparativa empreendida no presente estudo tem um caráter descritivo, dentro de uma perspectiva funcional, com o objetivo de melhor compreender como os países da common law estudados enfrentam o problema da crescente quantidade de conflitos envolvendo a concessão de benefícios sociais. Esses conflitos teriam o potencial de congestionar as cortes de justiça, afetando o acesso à justiça de segmentos menos favorecidos da sociedade, como demonstra o caso brasileiro. Não se buscou sugerir o transplante de instituições de um país para outro, dado que a cultura jurídica de um país é formada através de um processo jurídico e histórico que não pode ser exportado. ${ }^{11}$ Contudo, alguns aspectos do arranjo institucional dos países da common law podem indicar possíveis soluções para o caso brasileiro.

Neste artigo, eu sustento que o sistema brasileiro de adjudicação administrativa $^{12}$ dos conflitos previdenciários enfrenta dois problemas principais: a falta de independência do órgão administrativo responsável pela revisão das decisões iniciais que negam um benefício previdenciário e a ausência de normas procedimentais que assegurem a observância do devido processo legal na fase de revisão administrativa. Eu sugiro que essas deficiências conduzem à falta de confiança das partes no sistema administrativo de resolução de disputas e à excessiva judicialização dos conflitos

\footnotetext{
10 TENENBLAT, Fabio. Abuso no Acesso ao Judiciário: Custos Econômicos e Sociais. Dissertação de Mestrado. p. 12-20.

${ }^{11}$ HUSA, Jaakko. A New Introduction to Comparative Law. Portland: Hart Publishing, 2015. p.105-118.

${ }^{12} \mathrm{~A}$ adjudicação administrativa refere-se ao sistema de resolução de disputas individuais entre partes privadas e a Administração Pública, que se inicia com a decisão administrativa inicial, é seguida da fase de reconsideração ou revisão administrativa e se encerra com o controle judicial (ASIMOW, Michael. Five Models of Administrative Adjudication. American Journal of Comparative Law, 2015)
} 
previdenciários. Ao final, eu proponho sugestões para o aprimoramento do sistema brasileiro, com base na análise comparativa realizada com os países da common law.

Para desenvolver esse argumento, o artigo será estruturado em cinco seções. $\mathrm{Na}$ primeira seção, será apresentada a justificativa para a escolha dos conflitos previdenciários como objeto da análise comparativa, com base nos propósitos do Estado do bem-estar social. Eu irei demonstrar que os instrumentos desenvolvidos no Brasil para ampliar o acesso à justiça, tais como a assistência judiciária gratuita e os juizados especiais federais, não foram suficientes para conferir efetivo acesso e causaram uma sobrecarga das cortes de justiça. Na segunda seção, será feita uma análise descritiva dos sistemas de resolução dos conflitos previdenciários dos países mais representativos da common law: Reino Unido, Estados Unidos, Austrália e Canadá. Nesta seção, será apresentado o desenho institucional dos sistemas de resolução dos conflitos previdenciários daqueles países, as estatísticas de conflitos da fase da decisão inicial até o judicial review e considerações sobre a independência dos órgãos de adjudicação administrativa. A terceira seção será dedicada à análise descritiva do sistema de resolução dos conflitos previdenciários no Brasil. Nesta seção eu aponto as razões pelas quais considero que o órgão de adjudicação administrativa brasileiro não possui independência para decidir os conflitos previdenciários e revelo o problema da falta de garantias procedimentais na fase de adjudicação administrativa.Através de estatísticas, como a do número de casos que vai para o judiciário, por vezes sem sequer passar pelo sistema administrativo, eu sugiro que não há confiança das partes no sistema de revisão administrativa eque a judicialização excessiva dos conflitos previdenciários compromete o acesso à justiça e onera o orçamento público. Na quarta seção será desenvolvida uma análise comparativa dos diferentes sistemas, com o objetivo de realçar as vantagens e desvantagens do modelo brasileiro e analisar as razões pelas quais as cortes federais são vistas pelos reclamantes como o único local em que o conflito previdenciário pode ser resolvido com independência e de forma justa. A última seção buscará apresentar propostas de aprimoramento do sistema brasileiro de resolução de conflitos previdenciários, a fim de superaras deficiências apontadas e proporcionar um melhor acesso à justiça.

\section{Seção 1. Conflitos previdenciários como um problema de acesso a justiça}


A questão do acesso à justiça se manifesta em diversas esferas da vida em sociedade. Diante da impossibilidade de analisar todas essas dimensões no presente artigo, focaremos na questão previdenciária. A escolha pelo estudo dos conflitos de natureza previdenciária - que envolvem principalmente a concessão de benefícios por incapacidade do trabalhador, aposentadorias, pensões por morte, salário-maternidade e benefícios de amparo ao idoso e ao deficiente ${ }^{13}$ - deve-se ao fato de que a previdência social consistiu no primeiro e mais amplo esquema de proteção social desenhado pelo Estado do bem-estar para proteger o trabalhador e sua família dos riscos sociais que comprometem a sua renda.Os direitos previdenciários destinam-se à proteção do mínimo existencial do trabalhador e os conflitos que decorrem da negativa de uma prestação previdenciária pelo Estado possuem reflexos por vezes dramáticos na vida das pessoas. A análise dos conflitos previdenciários também se justifica porque eles correspondem à maioria dos litígios julgados pela Justiça Federal brasileira. Assim, o estudo de mecanismos alternativos de resolução destes litígios pode trazer reflexos positivos para o sistema judicial brasileiro, através da redução do acervo de processos e do tempo de processamento dos demais casos nas cortes federais.

Cappelletti (1988, p. 33-34) identificou a necessidade de criação de instituições e procedimentos para determinados tipos de causas de particular relevância social como uma das mais importâncias tendências do movimento de acesso à justiça. $\mathrm{O}$ autor ressalta que as cortes de justiça têm um papel permanente na efetivação e desenvolvimento dos direitos, especialmente nas causas de direito público, porém considera necessário reconhecer que as características do sistema judicial ordinário frequentemente se mostram inadequadas para a proteção dos direitos individuais das pessoas comuns, que usualmente não possuem conhecimento dos seus direitos e não propõem ações:

Nem o movimento considerável e contínuo em defesa dos interesses difusos, nem as técnicas gerais de diversificação podem atacar as barreiras à efetividade desses importantes novos direitos, ao nível individual. A grande tarefa dos reformadores do acesso à justiça é, portanto, preservar os tribunais ao mesmo tempo em que aperfeiçoam uma área especial do sistema judiciário que deverá alcançar esses indivíduos, atrair suas demandas e capacitá-los a desfrutar das vantagens que a legislação substantiva recente vem tentando conferir-lhes. (grifo nosso)

\footnotetext{
${ }^{13}$ Embora os benefícios de amparo ao idoso e ao deficiente integrem a política pública de assistência social (artigo 203, V da Constituição Federal), e não de previdência social, a operacionalização destes benefícios é feita inteiramente pela autarquia previdenciária.
} 
No que se refere especificamente à resolução de disputas entre cidadãos e o governo, já houve avanços marcantes no Brasil no acesso à justiça, com a criação dos Juizados Especiais Federais, no ano de 2002, que foram idealizados para proporcionar um procedimento informal, oral e célere para o julgamento de causas de pequeno valor contra o governo federal e suas agências administrativas, a exemplo do que já ocorria desde 1995 nos litígios envolvendo direito privado. Nessas cortes especializadas, o cidadão não possui custos para ajuizar uma ação e não necessita ser representado por um advogado. Por estas razões, os Juizados Especiais Federais foram especialmente utilizados para a resolução de conflitos previdenciários ${ }^{14}$, que usualmente envolvem pessoas com recursos limitados. A expectativa por ocasião da criação dos juizados especiais era de que houvesse uma correspondente redução dos casos previdenciários nas varas federais ordinárias, o que, contudo, não ocorreu. A quantidade de novos processos nos Juizados Especiais Federais atingiu 1,5 milhões de casos no ano de 2004, apenas dois anos após entrarem em funcionamento, e se manteve superior a 1 milhão de casos ano após ano desde então. Por outro lado, a quantidade de processos nas varas comuns não diminuiu substancialmente, o que sugere a existência de uma demanda reprimida de acesso à justiça ${ }^{15}$ :

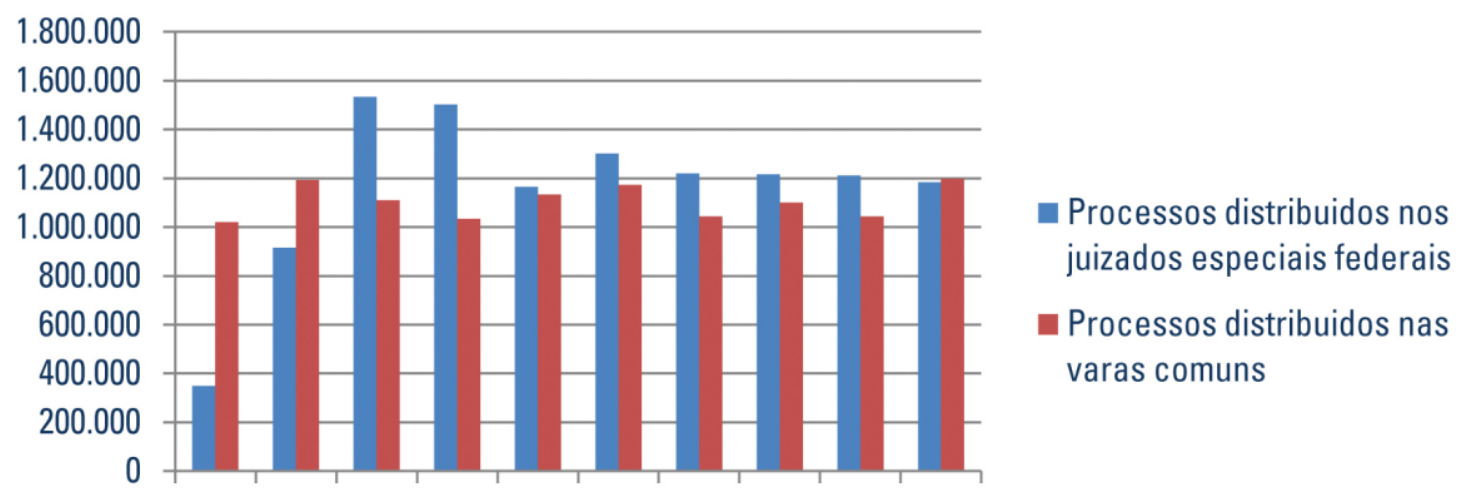

2002200320042005200620072008200920102011

Fonte: BRASIL/CJF, 2012. Elaboração: Diest/Ipea.

\footnotetext{
${ }^{14}$ Entre 2014 e 2016, cerca de 2,5 milhões novos processos foram ajuizados nos Juizados Especiais Federais envolvendo a concessão de benefícios previdenciários. (Dados obtidos nos Painéis do Conselho Nacional de $\quad$ Justiça, $\quad$ disponíveis $\quad \mathrm{em}$ https://paineis.cnj.jus.br/QvAJAXZfc/opendoc.htm?document=qvw_1\%5Cpainelcnj.qvw\&host=QVS\%40 neodimio03\&anonymous=true, acesso em 17/05/2018).

${ }^{15}$ Acesso à Justiça Federal: dez anos de juizados especiais / Instituto de Pesquisa Econômica Aplicada (Ipea) Brasília: Conselho da Justiça Federal, Centro de Estudos Judiciários, 2012.
} 
As promessas que levaram à criação dos Juizados Especiais Federais não se concretizaram. A expectativa de resolução rápida e simples dos litígios e a desnecessidade de representação por advogado estimularam o ajuizamento de milhões de processos a cada ano, o que terminou por comprometer a almejada celeridade destes novos órgãos judiciais. No final do ano de 2016, o tempo médio do processo pendente ${ }^{16}$ nos Juizados Especiais Federais era de um ano e três meses na fase de conhecimento, de três anos e onze meses na fase de recurso em segundo grau e de um ano e dois meses na fase de execução. Verifica-se, assim, que alguns processos demoram mais de cinco anos para serem concluídos nos juizados especiais, o que os aproxima da média encontrada nas varas ordinárias.

A informalidade e a oralidade também foram comprometidas. Com o objetivo de evitar acúmulo de processos e atrasos ainda maiores, os juízes deixaram de designar audiência para ouvir o reclamante e a oralidade cedeu espaço às petições e aos documentos escritos, mesmo naqueles casos nos quais apenas se discutem fatos, como ocorre usualmente nas disputas envolvendo a concessão de benefícios por incapacidade.

Essa "formalização" do procedimento nas cortes de pequenas causas também foi observada no direito comparado. Cappelletti (1988, p. 35) afirma que "muitos tribunais de pequenas causas tornaram-se quase tão complexos, dispendiosos e lentos quanto os juízos regulares (devido, particularmente, à presença dos advogados e à resistência dos juízes em abandonar seu estilo de comportamento tradicional, formal e reservado)". O autor sustenta que, sem algum tipo de procedimento para as pequenas causas, os direitos das pessoas comuns frequentemente permanecerão simbólicos.

Diante deste panorama, passaremos à análise comparativa dos sistemas de resolução de disputas previdenciárias entre os cidadão se o governo adotados em alguns países da common law e no Brasil, com o objetivo de identificar as semelhanças e as diferenças entre os sistemas e formular uma explicação para as causas dos problemas verificados no modelo brasileiro.

\section{A resolução dos conflitos previdenciários nos países da common law}

\footnotetext{
16 Processos pendentes são todos aqueles que nunca receberam movimento de baixa, em cada uma das fases analisadas.
} 
Nos países da common law, a adjudicação administrativa afeta diretamente uma quantidade muito maior de pessoas do que os sistemas de justiça criminal ou civil e envolve atividades extremamente sensíveis para o bem-estar social e a qualidade de vida das pessoas, tais como previdência e assistência social, saúde, imigração, educação e habitação. Por vezes, o sistema de justiça administrativa lida com conflitos envolvendo apenas partes privadas, resolvendo, por exemplo, litígios entre empregadores e empregados ou entre proprietários de imóveis e locatários. Os juízes e tribunais administrativos fornecem "justiça de massa" e um cidadão em disputa com o governo provavelmente terá seu "dia na corte" em um destes órgãos e não em uma corte de justiça ${ }^{17}$.

De uma maneira geral, a adjudicação administrativa nos países da common law pode ser dividida em dois modelos principais, de acordo com a localização institucional do órgão responsável pela resolução das disputas. O primeiro modelo é britânico, no qual a adjudicação é realizada por um órgão independente situado fora da agência, usualmente denominado de tribunal administrativo. Além do Reino Unido, esse modelo foi adotado pela Austrália e pelo Canadá. O segundo modelo é aquele no qual a adjudicação é executada por um juiz administrativo no interior de uma agência independente com funções combinadas, ou seja, que reúne poderes executivos, normativos e quase-judiciais. Esse modelo é típico do Estados Unidos.

\subsection{Reino Unido}

A estrutura atual da adjudicação administrativa no Reino Unido foi estabelecida pelo Tribunals, Courts and EnforcementAct (TCEA) de 2007, que fundiu diversos tribunais e criou uma estrutura de adjudicação administrativa de duas instâncias, compostas pelo First-tier Tribunal e pelo Upper Tribunal. O objetivo da reestruturação foi tornar os tribunais mais acessíveis aos usuários, mais eficientes e coerentes, preservando o tradicional sistema de especialização. Para isso, o First-tier Tribunal foi dividido em sete câmaras especializadas, que agruparam os tribunais até então existentes, a fim de que não houvesse perda da expertise dos seus membros. $\mathrm{O}$

\footnotetext{
${ }^{17}$ SOSSIN, Lorne. Access to Administrative Justice and Other Worries. In: FLOOD, Colleen \& SOSSIN, Lorne (Org.). Administrative Law in Context, 2 ed. Toronto: Edmond Montgomery Publications, 2013. p. 212.
} 
julgamento dos conflitos previdenciários é realizado pela Social Entitlement Chamber Social Security and Child Support. ${ }^{18}$

Os membros dos tribunais administrativos britânicos são nomeados para exercer mandato por termo fixo pelo Lord Chancelor, no caso do First-tier Tribunal, e pela Rainha, no caso do Upper Tribunal, após processo público seletivo organizado pelo Judicial Appointments Commission. ${ }^{19}$ Os membros destes tribunais possuem as mesmas garantias de independência asseguradas aos magistrados pelo Constitutional Reform Act 2005. ${ }^{20}$

O Department for Workand Pensions é o órgão responsável pela decisão inicial em relação à maioria dos benefícios previdenciários. Caso o interessado discorde da decisão inicial, deverá requerer reconsideração ao mesmo órgão (Mandatory Reconsideration), explicando as razões pelas quais considera a decisão incorreta e apresentando qualquer nova prova de que disponha. Caso a decisão inicial seja mantida, o reclamante pode apelar para o First-Tier Tribunal (Social Security andChild Support Chamber), que fará uma revisãode todos os aspectos fáticos e jurídicos do caso. Caso o reclamante não concorde com a decisão, poderá recorrer ao Upper Tribunal (Administrative Appeals Chamber), mas apenas em relação às questões legais, ou seja, aquelas que envolvem a interpretação de um princípio legal ou de um estatuto. Somente ao final da fase de adjudicação administrativa, o interessado poderá recorrer à Court of Appeal.

Abaixo o gráfico do fluxo de uma disputa previdenciária no sistema de adjudicação administrativa do Reino Unido:

\footnotetext{
${ }^{18}$ Cane, Peter. Administrative Tribunals and Adjudication. Oxford: Hart Publishing, 2010. p. 120.

${ }^{19}$ Cane, op. cit. p. 99.

${ }^{20}$ SEDLEY, Stephen. Lions Under the Throne: essays on the history of English public law. Cambridge: Cambridge University Press, 2015, p. 258.
} 


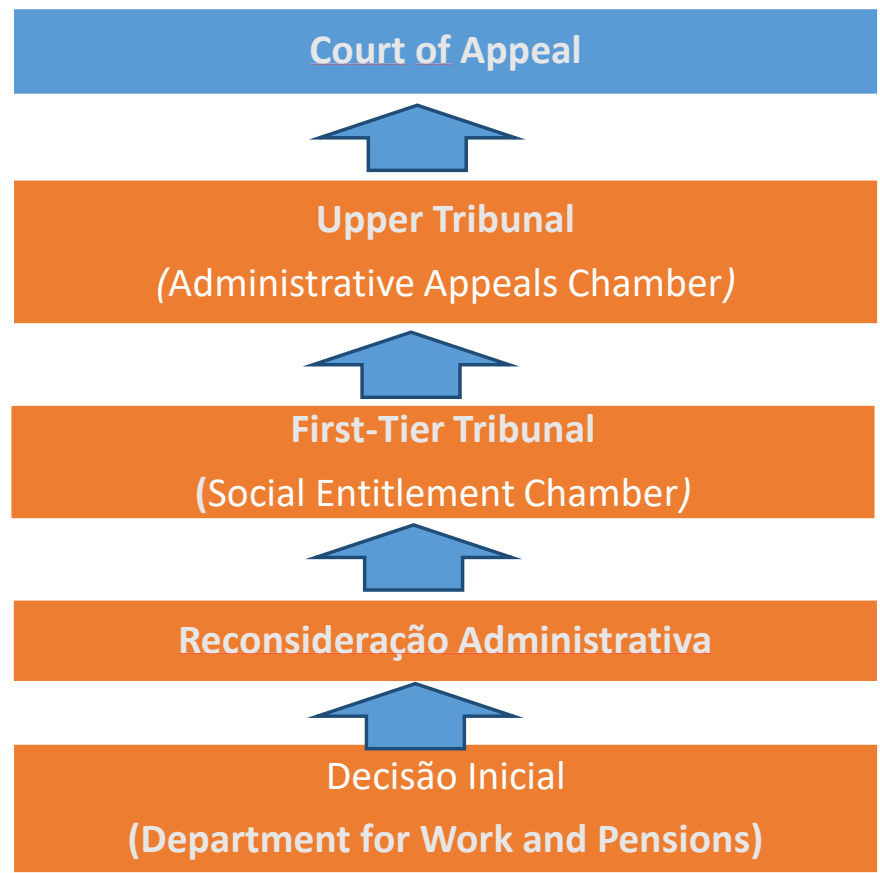

Passaremos à análise das estatísticas referentes aos conflitos envolvendo a concessão de um dos principais benefícios da previdência social no Reino Unido, o Employment and Support Allowance (ESA), que fornece uma renda para as pessoas doentes ou incapazes de trabalhar. Trata-se de benefício similar ao auxílio-doença e à aposentadoria por invalidez da previdência social brasileira. A comparação das estatísticas relacionadas à concessão de benefício por incapacidade ao trabalhador é útil para a compreensão das diferenças entre o sistema inglês e o brasileiro de adjudicação administrativa, já que em ambos os sistemas as disputas relativas a esse benefício são as mais recorrentes e que representam a maior parte do acervo dos tribunais e das cortes.

No período de outubro de 2013 a setembro de 2017, foram proferidas 2.100.000 decisões iniciais em requerimentos de ESA. Na fase seguinte (Mandatory Reconsideration), foram formulados cerca de 310.000 pedidos de reconsideração. No mesmo período, houve 173.731 pedidos de revisão ao First-Tier Tribunal e 20.211 apelações $^{21}$ ao Upper Tribunal. Por fim, apenas 31 casos envolvendo benefícios previdenciários foram julgados pela Court of Appeal no mesmo período (2013 a 2017)..$^{22}$

\footnotetext{
${ }^{21}$ A estatística do Upper Tribunal inclui todos os casos previdenciários, pois não há estatística detalhada referente ao Employment and Support Allowance (ESA).

${ }^{22}$ As estatísticas referentes às decisões iniciais e à Mandatory Reconsideration foram obtidas em https://assets.publishing.service.gov.uk/government/uploads/system/uploads/attachment_data/file/716083
} 
Abaixo o gráfico contendo as estatísticas dos conflitos envolvendo benefícios por incapacidade em cada uma das fases da adjudicação administrativa no Reino Unido:

Reino Unido - disputas relativas a benefícios por incapacidade(20132017)

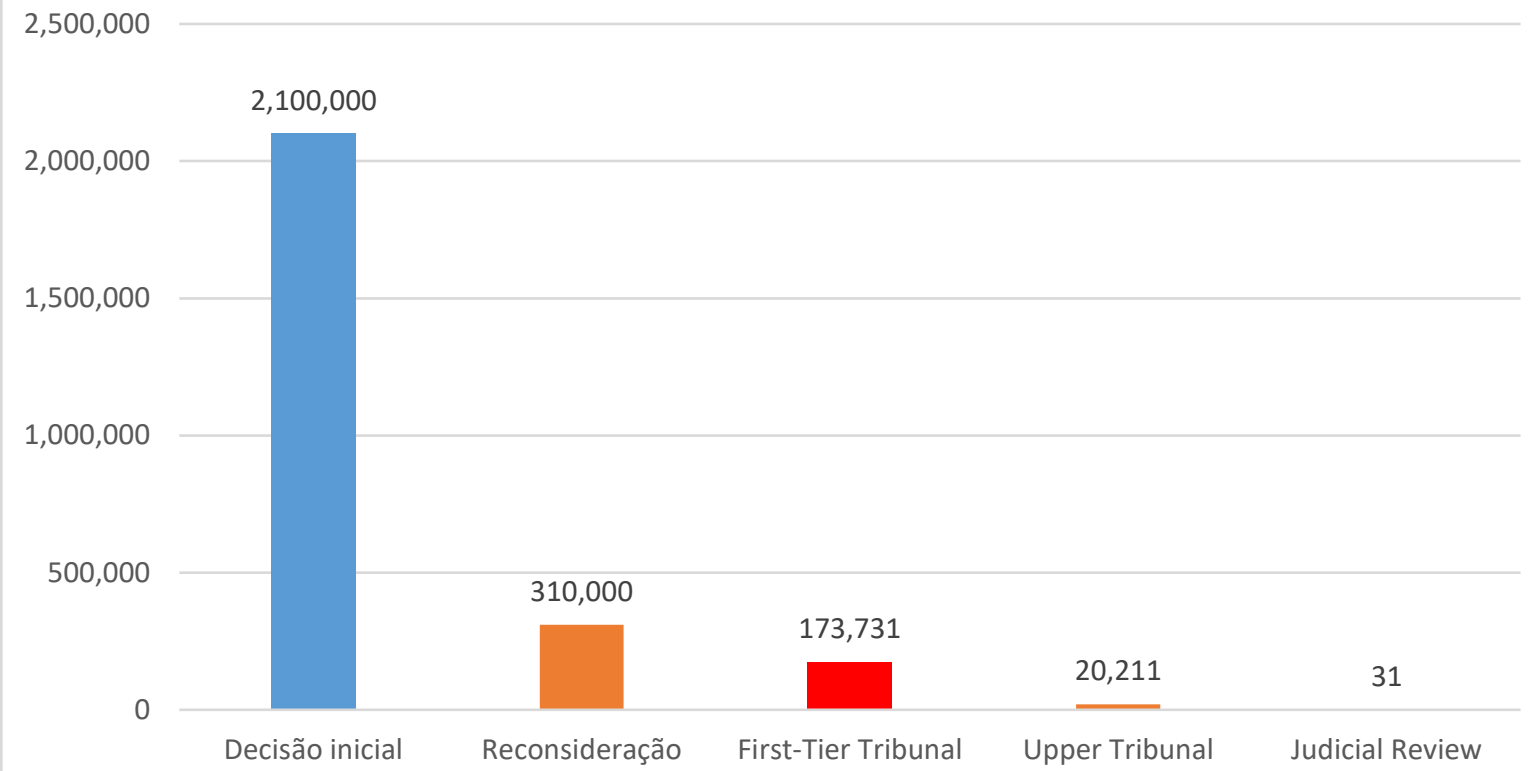

Verifica-se, portanto, que no Reino Unido a decisão administrativa inicial passa por diversos filtros até chegar à fase judicial. Dos cerca de 310 mil casos que foram apresentados na fase de reconsideração, apenas 31 chegaram ao judiciário, em um período de quatro anos. Note-se que essa depuração ocorreu sem que os direitos dos reclamantes fossem suprimidos, já que em cerca de $62 \%$ dos casos previdenciários levados aos tribunais administrativos a decisão foi favorável ao reclamante. ${ }^{23}$

\subsection{Estados Unidos}

Os Estados Unidos adotam o modelo de agências administrativas independentes com funções combinadas, no qual a regulamentação, a investigação, a persecução e a adjudicação são realizadas no interior da agência.

lesa-wca-summary-june-2018.pdf. As estatísticas referentes ao First-Tier Tribunal e ao Upper Tribunal foram obtidas em https://www.gov.uk/government/statistics/tribunals-and-gender-recognition-certificatestatistics-quarterly-october-to-december-2017 (MainTable: October to December 2017). As estatísticas referentes à Court of Appeals foram obtidas em http://www.bailii.org/ew/cases/EWCA/Civ/, acesso em 23/07/2018.

23 Informação disponível em https://www.gov.uk/government/collections/tribunals-statistics\#history, acesso em 26/06/2018. 
A fase de adjudicação administrativa dos conflitos previdenciários começa após a decisão inicial da agência previdenciária (Social Security Administration's SSA) que nega um benefício previdenciário. O requerente deve solicitar uma reconsideração à agência, que será analisada por um outro funcionário que não participou da decisão inicial. Na fase reconsideração será realizada uma completa revisão do caso e o requerente poderá apresentar novas evidências. O caso também é reavaliado por um outro médico ou psicólogo que não participou da avaliação inicial. ${ }^{24} \mathrm{Em}$ regra, não há audiência oral nesta fase, mas esta poderá ocorrer a pedido do interessado nos casos de benefício por incapacidade. Caso a decisão administrativa inicial seja mantida, o interessado pode solicitar uma audiência (presencial ou por videoconferência) perante um juiz administrativo (Administrative Law Judge - ALJ) vinculado à própria agência, que proferirá uma decisão com base na prova apresentada e no depoimento do interessado e de testemunhas, inclusive de médicos especialistas convocados para oferecer sua opinião sobre o caso. ${ }^{25}$ Caso o requerente discorde da decisão do juiz administrativo, poderá solicitar uma revisão ao Appeals Council, que também integra a estrutura da Social Security Administration. Caso a decisão mantenha-se desfavorável, o requerente pode ajuizar uma ação em uma Federal District Court. ${ }^{26}$

Abaixo o gráfico do fluxo de uma disputa previdenciária no sistema de adjudicação administrativa dos Estados Unidos:

\footnotetext{
24 Informação disponível em https://www.ssa.gov/legislation/testimony_072518.html, acesso em 29/07/2018.

25 Informação disponível em https://www.ssa.gov/legislation/testimony_072518.html, acesso em 29/07/2018.

${ }^{26}$ Informação disponível em https://www.ssa.gov/pubs/EN-05-10041.pdf, acesso em 28/07/2018.
} 


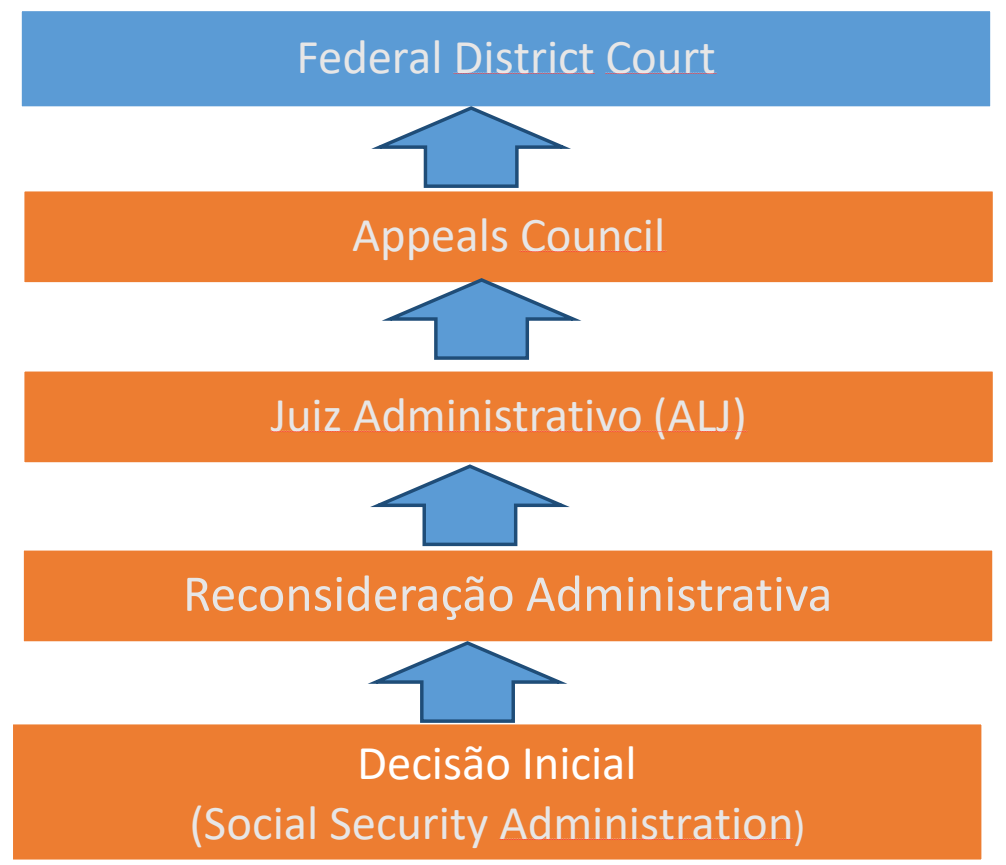

Os juízes administrativos norte-americanos são contratados por uma agência separada da agência em que trabalham (U.S. Office of Personnel Management), através de um rigoroso processo de testes e entrevistas, e possuem estabilidade desde a admissão. Eles somente podem ser removidos por justa causa, a ser apurada por um órgão específico de avaliação do mérito (Merit Systems Proctetion Board).

Tendo em vista que a resolução dos conflitos previdenciários ocorre no interior da própria agência administrativa responsável pela concessão dos benefícios, foram previstas uma série de garantias procedimentais e funcionais a fim de assegurar a independência dos juízes administrativos. Por exemplo, os funcionários das agências responsáveis pela investigação não podem se comunicar extra oficialmente com os juízes administrativos acerca dos casos em julgamento ou com os chefes das respectivas agências. Os juízes administrativos não podem desempenhar tarefas estranhas às suas funções e não estão subordinados ou sujeitos à supervisão por parte de funcionários da agência engajados em atividades de investigação ou persecução. Eles recebem os casos através de distribuição por rodízio, sempre que for praticável, e não podem ser avaliados pelas agências nas quais trabalham. ${ }^{27}$

\footnotetext{
${ }^{27}$ Essas garantias estão previstas no Administrative Procedure Act, 1946 (Section 5).
} 
Ao analisarmos as estatísticas dos conflitos previdenciários nos Estados Unidos, verificamos que a maior parte deles é resolvida pelo sistema extrajudicial de adjudicação administrativa. No ano fiscal de 2016, houve 1.800 .000 pedidos de benefícios por incapacidade à agência da previdência social. Na fase seguinte, foram formulados 648.000 pedidos de reconsideração. ${ }^{28}$ No mesmo período, houve 573.450 audiências perante os juízes administrativos ${ }^{29}$ e 136.987 pedidos de revisão ao Appeals Council..$^{30}$ Por fim, 17.864 casos $^{31}$ foram ajuizados a Federal District Court.

Abaixo o gráfico contendo as estatísticas dos conflitos envolvendo benefícios por incapacidade em cada uma das fases da adjudicação administrativa nos Estados Unidos:

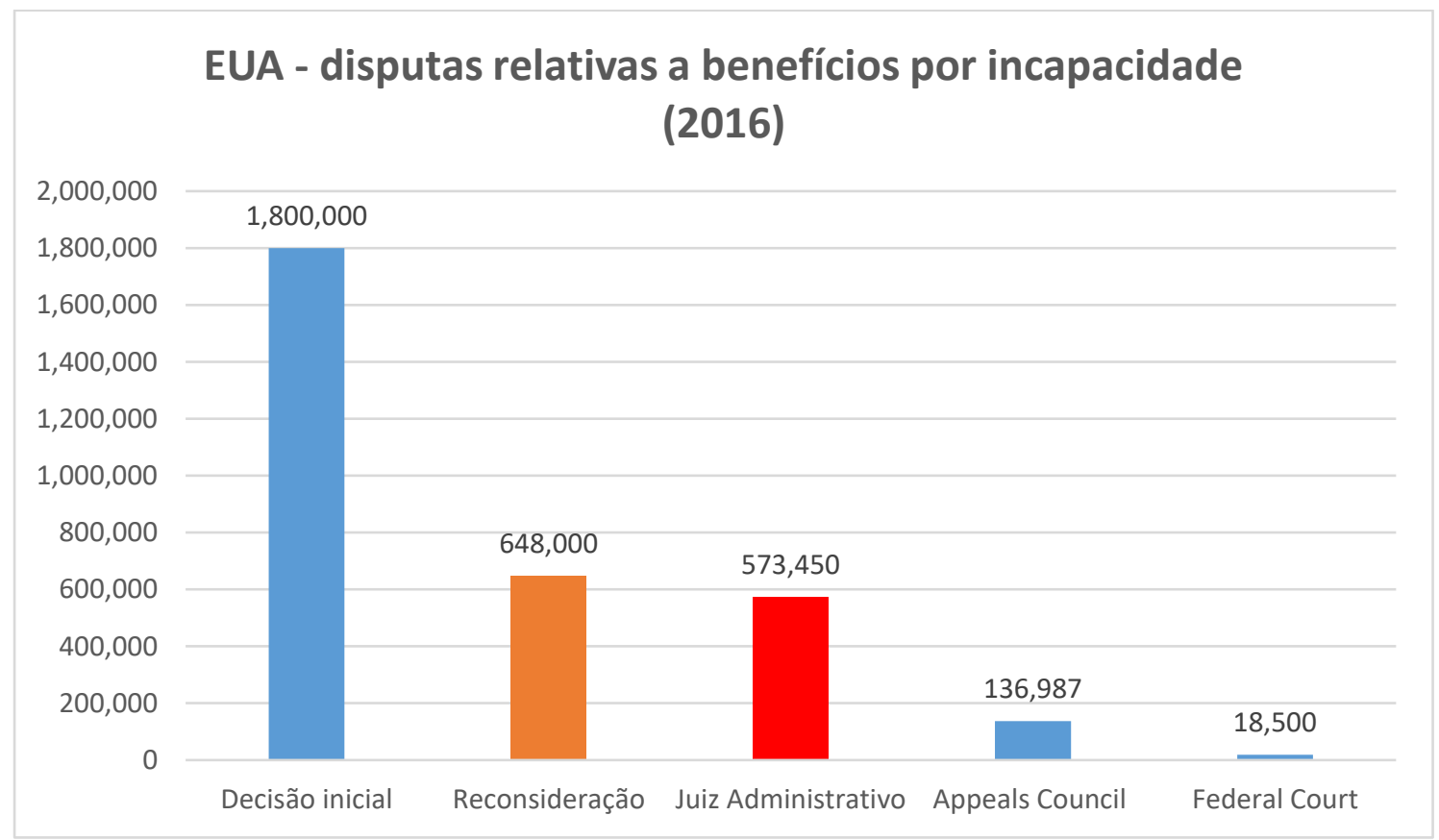

Ressalte-se, contudo,que a quantidade de casos previdenciários nas cortes federais é considerada excessiva, em especial aqueles envolvendo benefícios por incapacidade,e muitos autores sustentam que este fato decorre da inadequação do

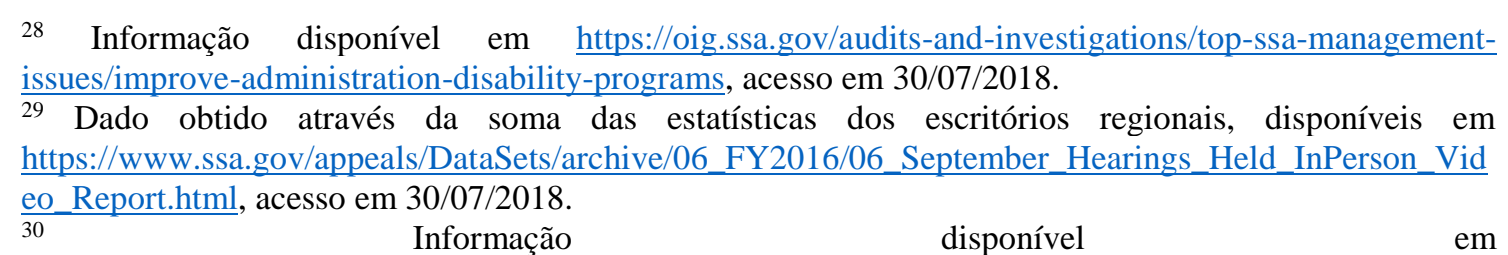
https://www.ssa.gov/appeals/DataSets/archive/07_FY2016/07_September_AC_Requests_For_Review.ht ml, acesso em 30/07/2018.

${ }^{31}$ https://www.ssa.gov/appeals/DataSets/AC04_NCC_Filed_Appealable.html 
modelo regulatório tradicional para as agências que lidam com a adjudicação de benefícios de massa ou que administram programas de larga escala. ${ }^{32}$ Ao longo dos anos, houve diversas propostas de criação de um tribunal administrativo especializado com o objetivo de controlar o aumento do volume de processos previdenciários nas cortes federais e proporcionar uma adjudicação especializada. ${ }^{33}$ Em pesquisa realizada entre os juízes federais norte-americanos, houve uma menção virtualmente unânime a esses casos como sendo os mais onerosos no dia-a-dia das cortes. De acordo com o Chief Judge do $6^{\circ}$ Circuito, Pierce Lively, os reclamantes poderiam obter uma resposta muito mais rápida em um tribunal administrativo especializado do que nas sobrecarregadas cortes federais distritais e de apelação. ${ }^{34}$

\subsection{Austrália}

O sistema da Austrália segue o modelo britânico de adjudicação administrativa externa à agência. ${ }^{35} \mathrm{O}$ Tribunal Administrativo de Apelação (AAT) é competente para rever o mérito de decisões administrativas de ministérios, departamentos e agências com base em mais de 400 estatutos efica investido de todos os poderes da autoridade originária, inclusive os discricionários, podendo confirmar, alterar ou substituir a decisão originária, ou determinar o seu retorno para reconsideração. ${ }^{36}$

Os membros do Tribunal Administrativo de Apelação não possuem as mesmas garantias asseguradas aos juízes, como estabilidade e proteção salarial, embora a independência do tribunal para efetuar a revisão de mérito das decisões administrativas sempre tenha sido reconhecida. ${ }^{37}$ Os membros do tribunal são nomeados para um mandato fixo de três, cinco ou sete anos e somente podem ser afastados por ordem do Parlamento, com base em mau comportamento ou incapacidade comprovados. ${ }^{38}$

\footnotetext{
${ }^{32}$ GIFFORD, Daniel. Adjudication in Independent Tribunals: The Role of an Alternative Agency Structure. In NotreDame Law Review, 1990, v. 66, p. 990.

${ }^{33}$.Houve 10 propostas de criação de um tribunal especializado em previdência social e 3 propostas de criação de uma corte judicial especializada que tramitaram no Congresso americano entre 1977 e 2000 (ERKUIL, Paul R; LUBBERS, Jeffrey S. Alternative Approaches to Judicial Review of Social Security. Disability Administrative Law Review, v . 55 , n. . 4, outono de 2003, p. 774-776).

${ }^{34}$ Ibid., p. 745.

${ }^{35}$ ASIMOW, Michael; LUBBERS, Jeffrey S.,The Merits of 'Merits' Review: A Comparative Look at the Australian Administrative Appeals Tribunal. Windsor Yearbook of Access to Justice, v. 28, n. 2, dez. 2010, p. 9. Disponível em https://ssrn.com/abstract=2782497, acesso em 29/11/2017.

${ }^{36}$ A partir de 01/07/2015, os Tribunais de Seguro Social, Migração e Refugiados foram fundidos ao AAT. Informação disponível em http://www.aat.gov.au/about-the-aat/what-we-do, acesso em 26/02/2018.

${ }^{37}$ O'CONNOR, Deirdre. Effective Administrative Review: An Analysis of Two-tier Review. Australian Journal of Administrative Law, v. 1, n. 1, nov. 1993.

${ }^{38}$ Cane, Peter. Administrative Tribunals and Adjudication. Oxford: Hart Publishing, 2010. p. 103
} 
A decisão inicial nos pedidos benefícios da previdência social é feita pelo Departamento de Serviços Humanos (Centrelink ${ }^{39}$ ). Caso o interessado não concorde com a decisão inicial, deverá solicitar uma reconsideração administrativa, que será efetuada por um funcionário do departamento que não participou da decisão inicial. Se a decisão não for revista, o reclamante pode recorrer ao Administrative Appeals Tribunal AAT (Social Services and Child Support Division). ${ }^{40}$ Caso não concorde com esta decisão, o interessado poderá recorrer à General Division do AAT. A decisão final do tribunal administrativo está sujeita a judicial review pela Federal Circuit Court e pela Federal Court.

Abaixo o gráfico do fluxo de uma disputa previdenciária no sistema de adjudicação administrativa na Austrália:

\section{Federal Court}
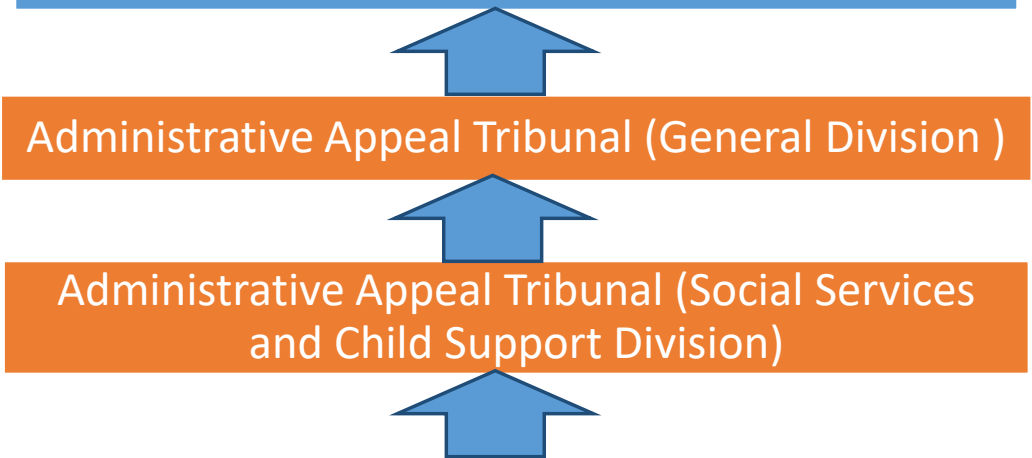

Reconsideração Administrativa

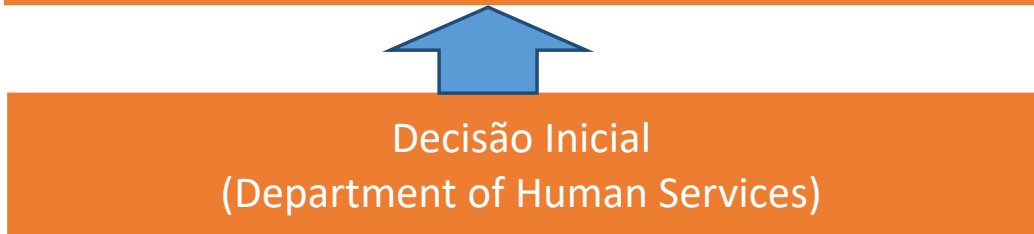

No exercício de 2016/2017, foram proferidas cerca de 97.000 decisões iniciais $^{41}$ relativas ao principal benefício por incapacidade (Disability Support

\footnotetext{
${ }^{39} \mathrm{https}: / /$ www.humanservices.gov.au/individuals/centrelink, acesso em 10/04/2018.

40 Informação disponível em https://www.humanservices.gov.au/individuals/enablers/reviews-andappeals-centrelink-decision/34671, acesso em 23/07/2018.

${ }_{41}$ Estatística disponível em https://www.humanservices.gov.au/sites/default/files/2017/10/8802-1710annual-report-2016-17.pdf, acesso em 23/07/2018.
} 
Pension $^{42}$ ). No mesmo exercício, o AAT recebeu 6.917 pedidos de revisão de decisões iniciais relativas ao mesmo benefício, que foi o assunto mais demandado na Social Services and Child Support Division. Na fase seguinte, houve 1.473apelações para a General Division. ${ }^{43}$ Por fim, apenas 15 casos envolvendo benefícios previdenciários julgados pela General Division foram objeto de judicial review na Federal Court ${ }^{44}$.

Abaixo o gráfico contendo as estatísticas dos conflitos envolvendo benefícios por incapacidade em cada uma das fases da adjudicação administrativa na Austrália:

\section{Australia - disputas relativas a benefícios por incapacidade (2017)}

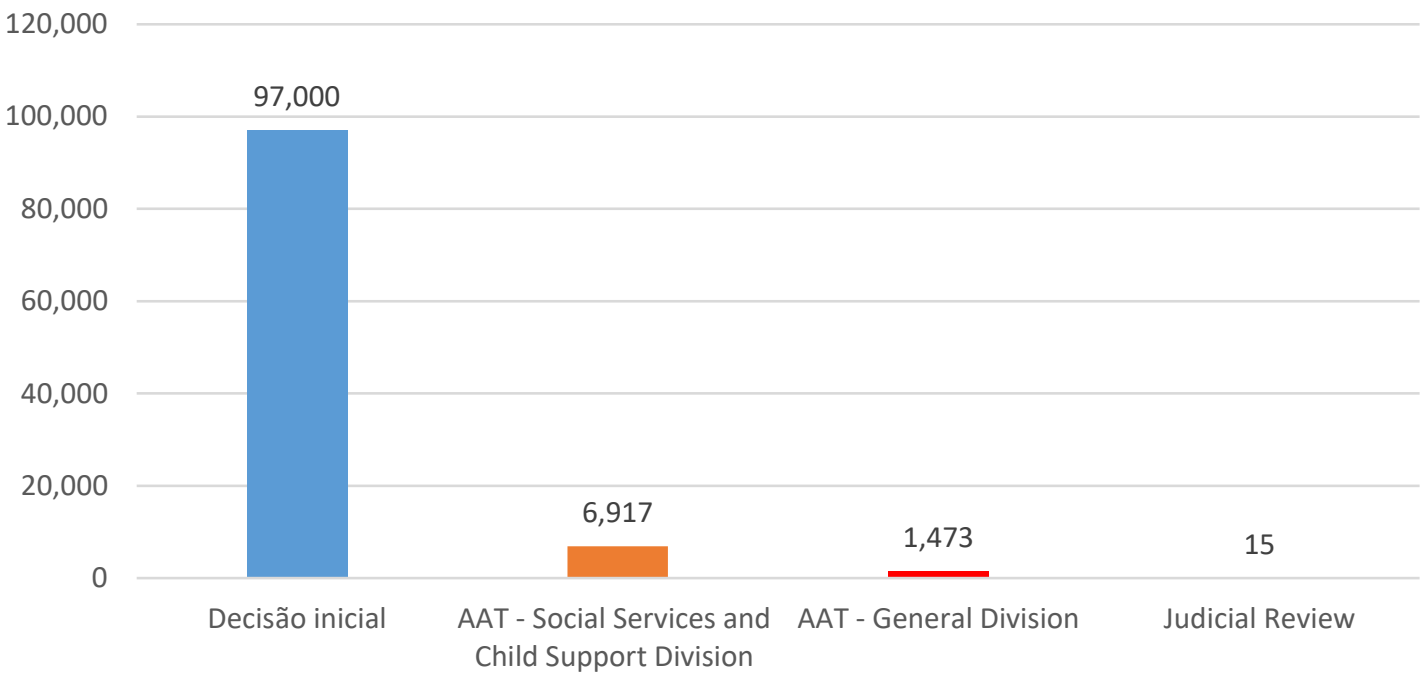

\subsection{Canadá}

Os tribunais administrativos do Canadá foram criados em uma base ad hoc e os arranjos institucionais variam amplamente de jurisdição para jurisdição. Por exemplo, no nível federal, existem vários tribunais isolados para a adjudicação de conflitos em matérias que se enquadram na jurisdição federal. ${ }^{45} \mathrm{Na}$ província de Quebec, existe um

42 Benefício devido em caso de incapacidade permanente para o trabalho (https://www.humanservices.gov.au/individuals/services/centrelink/disability-support-pension, acesso em 23/07/2018)

${ }^{43}$ Esse número corresponde a $60 \%$ do total de casos previdenciários decididos pela General Division. Informação constante no Administrative Appeals Tribunal AnnualReport 2016-2017 (p. 24), Disponível em http://www.aat.gov.au/AAT/media/AAT/Files/Reports/AR201617/AAT-Annual-Report-2016-17.pdf, acesso em 23/07/2018.

${ }^{44}$ Outros 23 casos envolvendo disputas previdenciárias relativas a benefícios para crianças e licença parental remunerada foram objeto de judicial review em face de decisão proferida pela primeira instância do AAT (Social Services andChildSupportDivision).

${ }^{45}$ São exemplos de tribunais administrativos federais: Canada Agricultural Review Tribunal, Canada Industrial RelationsBoard, Canadian Human Rights Tribunal, Federal Public Sector Labour Relations 
tribunal administrativo (Tribunal Administratif Du Québec) com quatro divisões competentes para o julgamento de conflitos ambientais, econômicos, imobiliários e assuntos sociais. ${ }^{46} \mathrm{Na}$ província de Ontário, houve uma gradual consolidação e reestruturação de vários tribunais administrativos, que foram agrupados dentro de uma mesma organização de acordo com as matérias analisadas. ${ }^{47}$

Normalmente, os membros do tribunal são nomeados por períodos fixos que variam de três a sete $\operatorname{anos}^{48}$. Jurisdições menores, como as quatro províncias do Atlântico, adotam o modelo de serviço comunitário, com juízes trabalhando meio expediente. Nas províncias da Colúmbia Britânica e de Ontário, foi estabelecido um processo de nomeação dos membros dos tribunais baseado no mérito, com consulta prévia ao presidente do tribunal. Por outro lado, os membros do Tribunal Administrativo do Quebec possuem estabilidade na função e, para a maioria dos efeitos práticos, são tratados como se fossem juízes dacorte de justiça da província ${ }^{49}$.

As disputas relacionadas à concessão de benefícios previdenciários na esfera federal são resolvidas pelo Tribunal de Previdência Social (Social Security Tribunal). ${ }^{50}$ As decisões administrativas iniciais acerca de benefícios previdenciários são proferidas pelo Minister of Employment and Social Development Canada. Caso o interessado não concorde com a decisão, deverá solicitar uma reconsideração, que será analisada por um funcionário do ministério que não esteve envolvido na decisão inicial. ${ }^{51}$ Caso ainda esteja insatisfeito, o interessado poderá recorrer para a General Division do Social Security Tribunale, em seguida, para a Appeals Divisond o Social

and EmploymentBoard, Social Security Tribunal, Transportation Appeal Tribunal of Canada, dentre outros.

${ }^{46}$ CREYKE, Robin. Tribunals in the Common Law World. Sydney: The Federation Press, 2008

${ }^{47}$ Há três organizações (clusters) de tribunais administrative em Ontario: Social Justice Tribunals Ontario (SJTO), Environment and Land Tribunals Ontario (ELTO) e Safety License Appeals and Standards Tribunal Ontario (SLASTO). Juntos, os três clusters decidem conflitos baseados em 140 estatutos e recebem aproximadamente 160.000 casos anualmente. Para efeito de comparação, a Corte Superior de Ontario recebe 95.000 novos casos e os Juizados Especiais (Small Claims Court) recebem 45.000 casos a cada ano. (http://www.sjto.gov.on.ca/documents/sjto/The\%20SixMinute\%20Administrative\%20Lawyer\%202014.html, acesso em 22/05/2018)

48 Os membros do Social Security Tribunal são nomeados pelo Governador-Geral do Canadá (sob orientação do Gabinete de ministros) para um mandato de 5 anos.

${ }^{49}$ BRYDEN, Philip. A Canadian Perspective of Tribunal Independence. Melbourne: The Australasian Institute of Judicial Administration 2013. Disponívelemhttp://www.coat.gov.au/images/downloads/tas/Tribunal\%20Independence.pdf, acesso em 27/06/2018.

${ }^{50} \mathrm{O}$ tribunal decide recursos contra decisões baseadas no Employment Insurance Act, Canada Pension Plane Old Age Security Act (Informação disponível em https://www1.canada.ca/en/sst/, acesso em 20/03/2018).

51 Informação disponível em https://www.canada.ca/en/services/benefits/publicpensions/cpp/cppdisability-benefit/after-apply.html, acesso em 24/07/2018. 
Security Tribunal. O judicial review das decisões de última instância do Social Security Tribunal é feito pela Federal Court e pela Federal Court of Appeal. ${ }^{52}$ Abaixo o gráfico do fluxo de uma disputa previdenciária no sistema de adjudicação administrativa no Canadá:

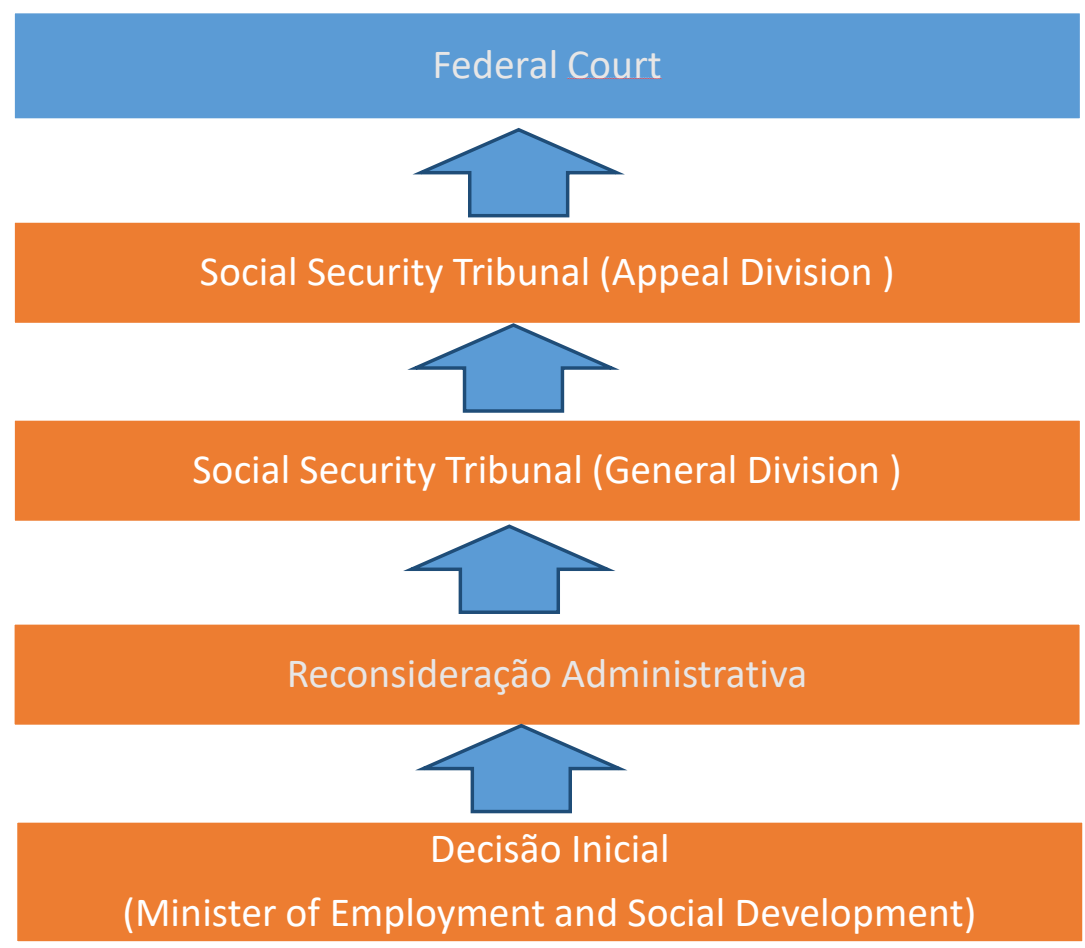

No exercício fiscal 2016/2017, o ministério proferiu 1.285.000 decisões iniciais referentes aos principais benefícios previdenciários. ${ }^{53}$ Foram formulados 13.000 pedidos de reconsideração (sendo 12.000 pedidos referentes a benefícios por incapacidade), dos quais $43 \%$ foram aceitos. ${ }^{54}$ No mesmo período, a General Division do Social Security Tribunal (Income Security Section) recebeu 3.628 novos casos, sendo que em $27 \%$ a decisão inicial foi reformada e em $14 \%$ houve acordo entre as partes. A Appeal Division (Income Security Section) recebeu 645 novas apelações, sendo 40\% providas e $16 \%$ concluídas por acordo. Por fim, a Federal Court recebeu 14 pedidos de

\footnotetext{
52 A maioria das decisões da Appeal Division está sujeita a judicial review pela Federal Court of Appeal. Contudo, o Federal CourtsAct, parag, 28(1) $(g)$ indica os tipos de decisões que estão sujeitas a judicial review pela Federal Court, tais como as decisões da Appeals Division que rejeitam sumariamente uma apelação ou as que negam ou deferem um pedido de leaveto appeal.

53 Estatística referente aos seguintes benefícios: Retirement Pensions, Disability Pensions e Postretirement benefits.

54 Informação disponível em https://www.canada.ca/content/canadasite/en/employment-socialdevelopment/programs/pensions/reports/annual-2017.html\#h8, acesso em 24/07/2018.
} 
judicial review e a Federal Court of Appeal recebeu 27 pedidos de judicial review. Destes, as cortes federais reviram as decisões do tribunal administrativo em 12 casos (29\%) para conceder um benefício previdenciário ao reclamante: ${ }^{55}$

Abaixo o gráfico contendo as estatísticas dos conflitos envolvendo benefícios previdenciários em cada uma das fases da adjudicação administrativa no Canadá:

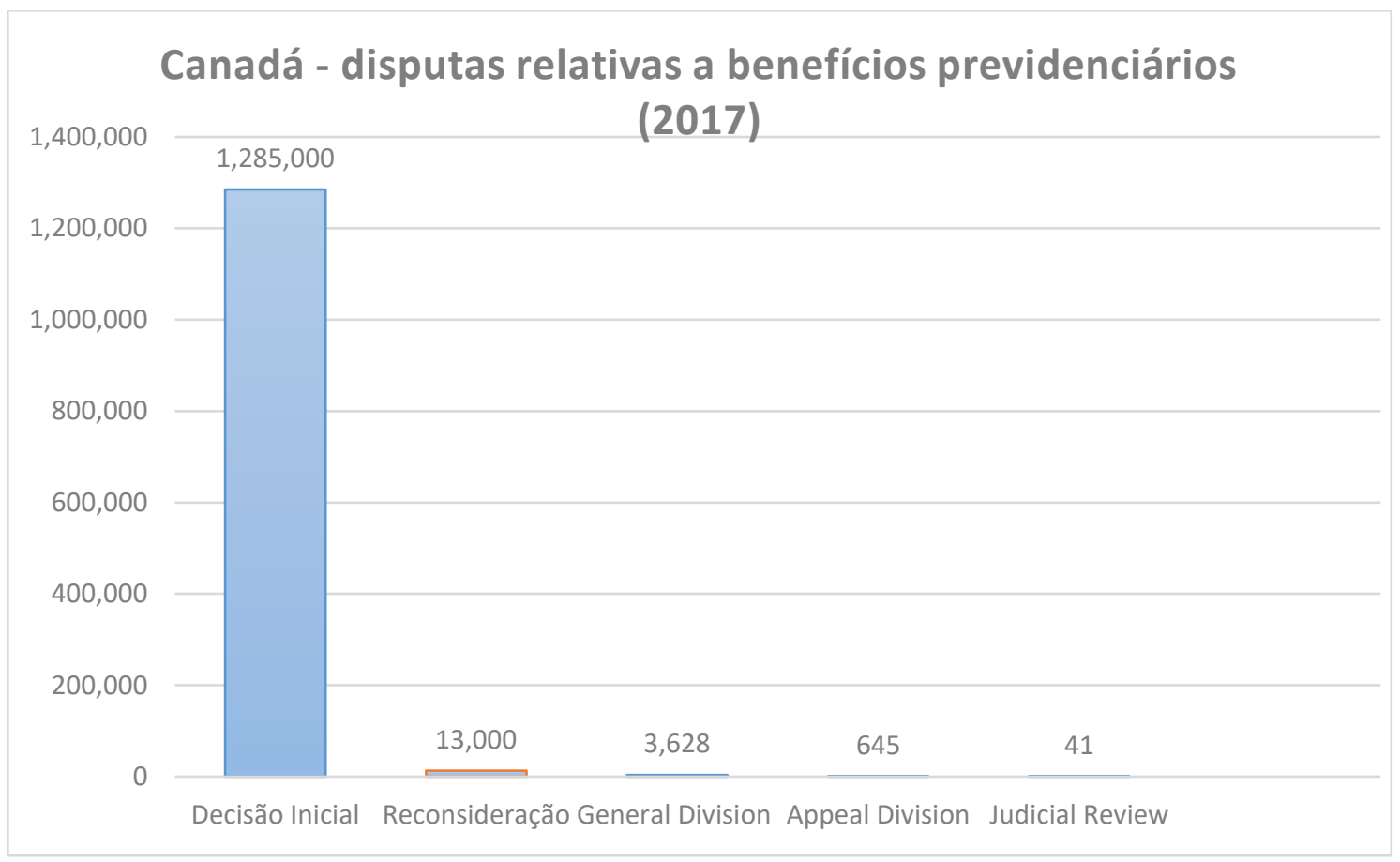

\section{A resolução dos conflitos previdenciários no Brasil}

No Brasil, o Instituto Nacional do Seguro Social é agência administrativa responsável pela concessão dos benefícios previdenciários. Apesar de possuir personalidade jurídica própria, o INSS não se caracteriza como uma agência independente, pois o seu presidente é nomeado livremente pelo ministro responsável pela área e pode ser exonerado a qualquer tempo sem justo motivo.

Em caso de indeferimento do pedido de um benefício previdenciário, o interessado pode solicitar a revisão da decisão ao Conselho de Recursos da Previdência Social, que possui duas instâncias administrativas: as Juntas de Recursos da Previdência

55 Informação disponível em http://www1.canada.ca/en/sst/rdl/annualreport-2016-2017.html\#5.1, acesso em 25/03/2018. 
Social ( $1^{\mathrm{a}}$ instância administrativa), localizadas nos Estados da federação, e as Câmaras de Julgamento ( $2^{\mathrm{a}}$ instância administrativa), localizadas na capital do país.

Cada Junta ou Câmara de Recurso é composta por quatro membros, sendo dois representantes do governo, um representante das empresas e um representante dos empregados, nomeados pelo governo para um mandato de dois anos.

O Conselho de Recursos da Previdência Socialé um órgão subordinado ao ministro, sem autonomia administrativa ou orçamentária e seus membros não possuem garantias para atuar comindependência. O governo possui maioria do quórum dos julgamentos e um de seus representantes deve ser necessariamente o presidente do órgão, de modo que há um desequilíbrio na resolução das disputas em favor do governo. Apesar de serem nomeados para um mandato de dois anos, os membros do Conselho podem ser demitidos pelo ministro por uma série de motivos, dentre os quais a insuficiência de desempenho, seja no aspecto quantitativo ou qualitativo, o que permite que os conselheiros sejam afastados até mesmo em razão do conteúdo de suas decisões. ${ }^{56}$

Ademais, não há garantias procedimentais que assegurem um contraditório efetivo, como a previsão de uma audiência oral perante o Conselho para a produção e impugnação de provas.A previsão de garantias procedimentais seria particularmente importante na fase de reconsideração que se dá perante o Conselho, já que não há qualquer garantia processual na fase da decisão administrativa inicial.

Por fim, o Conselho de Recursos está expressamente proibido de afastar a aplicação, por ilegalidade ou inconstitucionalidade, de decreto ou de qualquer ato ministerial, salvo quando já houver decisão vinculante do Supremo Tribunal Federal. ${ }^{57}$ Assim, o Conselho deve seguir as orientações do ministério ao interpretar e aplicar a lei em um caso concreto.

A preferência das partes pela revisão judicial em detrimento da fase de revisão administrativa é claramente demonstrada pela comparação das estatísticas entre os casos decididos pelo Conselho de Recursos e pela Justiça Federal.No ano de 2016, o Conselho de Recursos da Previdência Social recebeu 3.446casos envolvendo a concessão de benefícios por incapacidade, ao passo que a Justiça Federal recebeu cerca de um milhão de processos versando sobre a mesma questão, que foi o assunto mais

\footnotetext{
56 Regimento Interno do CRPS, disponível em http://www.previdencia.gov.br/arquivos/office/1_121220102751-326.pdf, acesso em 10/03/2018.

57 Artigo 70 do Regimento Interno do CRPS.
} 
demandado em todo o judiciário federal naquele ano ${ }^{58}$.

Abaixo o gráfico contendo as estatísticas dos conflitos envolvendo benefícios por incapacidade no Brasil:

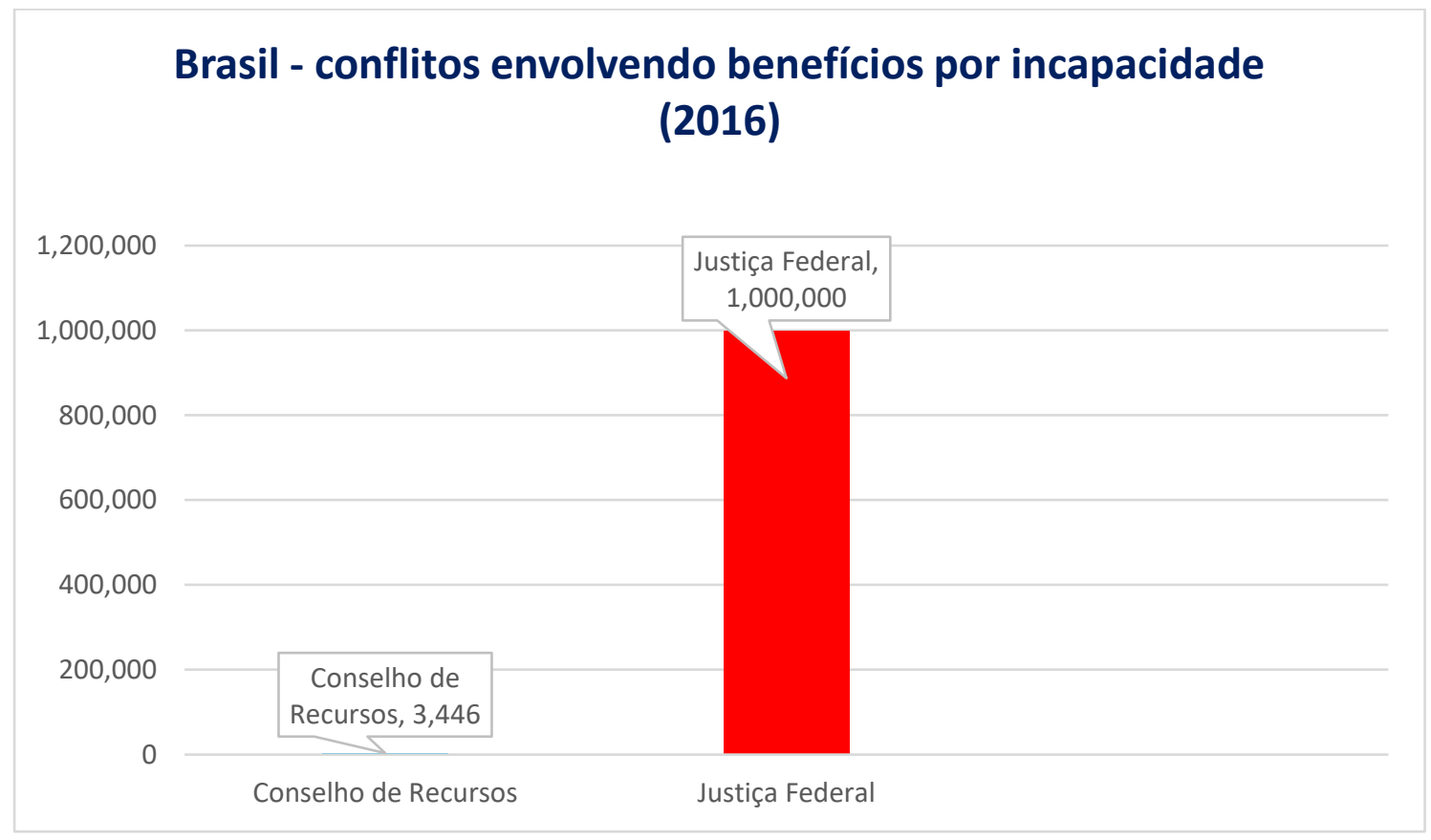

A maior parte dos casos apresentados nas cortes federais envolve predominantemente a verificação de questões fáticas relacionadas à capacidade laborativa do trabalhador e ao preenchimento dos requisitos para a obtenção de benefícios (carência, qualidade de segurado, etc), consumindo uma grande parte de recursos humanos e financeiros, além do tempo dos magistrados. É importante ressaltar que os custos com os honorários do perito médico e dos advogados dos reclamantes em caso de assistência judiciária gratuita ${ }^{59}$ (que correspondem à grande maioria dos casos) são pagos com recursos do orçamento do próprio Poder Judiciário, de modo que o impacto financeiro destas ações para a sociedade é bastante significativo ${ }^{60}$.

\footnotetext{
${ }^{58}$ Dados extraídos do Relatório Justiça em Números-2015 do Conselho Nacional de Justiça e do Anuário Estatístico da Previdência Social - 2016.

${ }^{59}$ A despesa orçamentária com assistência judiciária gratuita na Justiça Federal passou de cerca de R $\$ 4,7$ milhões, em 2001, para de R\$ 142 milhões, em 2013, representando uma variação da ordem de $2.891 \%$. Informação disponível emhttp://www5.cjf.jus.br/cjf/noticias/2012/agosto/cjf-aprova-propostaorcamentaria-de-r-7-5-bilhoes-para-a-justica-federal, acesso em 03/10/2017.

${ }^{60}$ Ao final do processo a parte que perde o processo deve reembolsar a Justiça Federal. Contudo, somente há reembolso se a parte não for beneficiária da assistência judiciaria ou se o perdedor for o INSS. Nesta última hipótese, os recursos também saem do orçamento público.
} 
Por fim, o Instituto Nacional do Seguro Social figurou como o maior litigante judicial do país, nos anos de 2011 e 2012, considerando-se todos os processos que tramitam nas Justiças Estadual, Federal e do Trabalho. O INSS foi parte em aproximadamente $34 \%$ do total de processos ajuizados na Justiça Federal de $1^{\circ}$ Grau e $79 \%$ nos Juizados Especiais Federais. ${ }^{61}$

\section{Análise Comparativa dos Diferentes Sistemas}

A expansão do Estado do bem-estar social ocorrida a partir do início do século $\mathrm{XX}$ em diversos países trouxe desafios comuns relacionados ao acesso à justiça. A crescente busca pela implementação dos direitos sociais evidenciou a necessidade da criação ou reforma de mecanismos e instituições para viabilizar o acesso a esses direitos quando negados pelo Estado. Verificamos que a maior parte dos conflitos previdenciários nos países da common law estudados é decidida através de adjudicação administrativa, que é realizada no interior da agência administrativa nos Estados Unidos e por tribunais administrativos no Reino Unido, Canadá e Austrália. Em todos os casos, a adjudicação é especializada, exigindo-se dos adjudicadores qualificação técnica na matéria previdenciária.

Também se constatou que a adjudicação dos conflitos é realizada por agentes públicos dotados de relativo grau de independência funcional, sendo que no Reino Unido a proteção se dá em grau máximo, pois os membros dos tribunais possuem as mesmas garantias dos magistrados. Nos Estados Unidos os juízes administrativos possuem estabilidade na função e proteção salarial, ao passo que no Canadá e na Austrália os adjudicadores são nomeados para exercer um mandato por tempo fixo e possuem certo grau de proteção contra a despedida imotivada.

Nos países da common law estudados há garantias procedimentais que asseguram o contraditório efetivo e a ampla produção de provas na fase de revisão administrativa, o que resulta em um controle judicial deferente e muito menos abrangente do que ocorre no Brasil. A revisão judicial normalmente é fechada, o que significa dizer que as partes não podem apresentar novas evidências ou argumentos que não foram deduzidos na esfera administrativa. Ascortes de justiça devem manter a

61 Relatórios “100 Maiores Litigantes do País”, anos de 2011 e 2012, disponíveis em http://www.cnj.jus.br/images/pesquisas-judiciarias/pesquisa_100_maiores_litigantes.pdf

http://www.cnj.jus.br/images/pesquisas-judiciarias/Publicacoes/100_maiores_litigantes.pdf, acesso em 30/08/2017. 
razoável conclusão sobre os fatos feita pela agência, bem como o exercício razoável do poder discricionário. ${ }^{62}$

Esse modelo parece explicar a prevalência da adjudicação administrativa em relação à resolução judicial dos conflitos nestes países. A adjudicação administrativa, em regra, é mais barata, mais rápida, mais informal e mais especializada do que a judicial. A independência e a imparcialidade da adjudicação administrativa se refletem no considerável percentual de reforma de decisões iniciais equivocadas e parecem reforçar a confiança das partes no sistema. Ademais, o reclamante somente pode recorrer ao Judiciário após o esgotamento de toda a instância administrativa, ao contrário do que ocorre no Brasil, de modo que a judicialização é vista como a última opção do reclamante.

Por outro lado, o Brasil também conta com um órgão para a resolução extrajudicial dos conflitos previdenciários, o Conselho de Recursos da Previdência Social, cuja estrutura foi descrita anteriormente. Contudo, a adjudicação administrativa é realizada por agentes que não contam com independência funcional, pois a maioria dos membros do Conselho de Recursos é composta por funcionários do governo, que retornam às suas funções após o término do mandato. ${ }^{63}$ Todos os membros do Conselho, incluindo os representantes de empregados e empregadores, podem ser afastados durante o mandato em razão de não atingirem metas quantitativas e qualitativas estabelecidas pelo ministério. Os recursos humanos e materiais necessários ao funcionamento do Conselho de Recursos são providos pelo ministério, o que acentua a dependência do órgão em relação ao governo.

Além disso, não há garantias procedimentais que assegurem a produção de provas e o contraditório efetivo na fase de revisão administrativa.Por exemplo, a partir da Constituição de 1988, que conferiu à união estável os mesmos efeitos jurídicos do casamento civil, ${ }^{64}$ tornaram-se bastante frequentes pedidos de pensão em razão da morte de segurado da previdência social sob a alegação de união estável. Muitos desses

\footnotetext{
${ }^{62}$ ASIMOW, Michael. Five Models of Administrative Adjudication. American Journal of Comparative Law, 2015. Disponível em: http://bit.ly/1yp8y4i, acesso em 02/04/2018.

63 A Corte Federal de Apelação do Canada decidiu que a nomeação de um funcionário do Ministério da Imigração como membro de um tribunal administrativo que revê decisões do mesmo ministério cria uma razoável suspeita de parcialidade, em razão dos efeitos que suas decisões podem ter em sua carreira ao retornar para suas funções.

(In Ahumada v. Canada [Minister of Citizenship and Immigration] [2001], 199 D.L.R., apud Ronald Ellis, Unjust by Design: Canada's Administrative Justice System, Vancouver: UBC Press, 2013. p. 76.)

${ }^{64}$ Artigo 226, $\$ 3^{\circ}$ da Constituição da República Federativa do Brasil.
} 
pedidos são negados pela agência administrativa sob o fundamento de falta de provas da relação de companheirismo. Trata-se, portanto, de matéria eminentemente fática. Contudo, se o reclamante recorrer ao Conselho de Recursos da Previdência Social não terá o direito de comparecer a uma audiência a fim de apresentar novas provas, convocar testemunhas e ser ouvido. O reclamante somente poderá apresentar alegações escritas e a prova a ser considerada é aquela que foi produzida pela agência, sem contraditório e ampla defesa. Embora o advogado do reclamante tenha o direito à palavra no dia da sessão de julgamento (quando a decisão do juiz relator já estará pronta e nenhuma prova será produzida), essa garantia não se mostra suficiente para que seja assegurado o devido processo legal na fase de adjudicação administrativa.

$\mathrm{O}$ atual desenho institucional da adjudicação dos conflitos previdenciários no Brasil faz com as partes não busquem a revisão administrativa no caso de uma decisão inicial desfavorável e ingressem diretamente com uma ação judicial perante a Justiça Federal, que realizará uma revisão de novo.Na fase judicial, as partes possuem ampla oportunidade de produção de provas, podendo requerer perícias médicas, oitivas de testemunhas, inspeções, requisições de documentos, etc. No caso acima dado como exemplo, o reclamante poderá convocar testemunhas em juízo para comprovar a união estável, apresentar novos documentos, prestar seu depoimento pessoal e solicitar qualquer providência judicial que seja razoável e apta a provar as suas alegações.A consequência natural deste modelo é o reduzido, senão inexistente, grau de deferência dos juízes às decisões administrativas previdenciárias, tendo em vista que o juiz está melhor posicionado para decidir o conflito do que o administrador, em razão de ter participado de toda a atividade probatória em um processo conduzido de forma adversarial.

No modelo brasileiro, as chances de reforma da decisão administrativa inicial são maiores nas cortes de justiça, o que parece explicar a preferência pela revisão judicial em detrimento da adjudicação administrativa. Esse modelo apresenta algumas vantagens para o reclamante, como a possibilidade de ter o seu pedido reapreciado por uma autoridade que pertence a uma estrutura estatal completamente independente daquela a que pertence a autoridade decisória, afastando as preocupações usualmente suscitadas nos países da common law acerca da independência e imparcialidade dos membros dos órgãos de adjudicação administrativa.

O que se verifica é que, na prática, os juízes brasileiros vêm desempenhando 
uma função análoga àquela exercida pelos juízes administrativos e membros dos tribunais administrativos da common law. Em razão da ausência de um sistema independente de adjudicação administrativa no Brasil, o judiciário foi compelido a assumir a atividade de produção de provas e a assegurar o " dia na corte" ao reclamante, que, de outro modo, não teria acesso a uma resolução justa de seu conflito. ${ }^{65}$

Não obstante, esse modelo trouxe consequências indesejadas. Considerando que as cortes federais são vistas pelos reclamantes como o único local em que o conflito previdenciário pode ser resolvido com independência e de forma justa, houve superutilização do sistema judicial, causando a sobrecarga das cortes e uma expressiva demora no julgamento destes casos. Como foi realçado anteriormente, a demanda latente por uma adjudicação justa e rápida dos conflitos previdenciários foi atendida, inicialmente, pelos juizados especiais federais, criados no ano de 2002 com o objetivo de ampliar o acesso à justiça nos litígios contra o governo federal. Contudo, este sistema parece não ser mais capaz de atender a demanda de forma satisfatória, o que pode ser demonstrado pela progressiva perda da celeridade e da oralidade que inicialmente haviam justificado a sua criação.

Outra consequência indesejada é o alto índice de benefícios concedidos diretamente por determinação judicial, considerando que os juízes brasileiros usualmente não restituem o caso à agência administrativa para que reanalise o pedido, ao contrário do que ocorre nos países da common law. O alto de índice de concessões judiciais desorganiza a atividade administrativa e causa descontrole orçamentário. ${ }^{66}$

O custo para o país com o modelo predominantemente judicial de resolução de disputas tem sido alto. A Justiça Federal vem se expandindo de forma acelerada nos últimos anos, em especial o sistema dos juizados especiais federais, com o objetivo de atender ao grande volume de novos processos.Entre 2003 e 2013, as despesas totais da Justiça Federal aumentaram de R $\$ 2,7$ bilhões para R \$ 10,5 bilhões, um aumento de

65 "Se os dados evidenciam predomínio das demandas previdenciárias e assistenciais nos juizados federais, o outro lado dessa realidade é justamente o fato de que o INSS é o grande réu das ações e que boa parte dos atos processuais praticados ao longo da tramitação judicial reproduzem ou, o que é mais grave, substituem procedimentos que deveriam ter ocorrido de forma adequada na esfera administrativa" (Acesso à Justiça Federal: dez anos de juizados especiais / Instituto de Pesquisa Econômica Aplicada (Ipea) Brasília: Conselho da Justiça Federal, Centro de Estudos Judiciários, 2012.

${ }^{66}$ Em fevereiro de 2014, 15\% do total de benefícios por incapacidade foram concedidos judicialmente, o que representou uma despesa mensal de R\$ 1,042 bilhões. Fonte: Relatório de Fiscalização do Tribunal de Contas da União $\quad$ TC $\quad 010.604 / 2014-6 . \quad$ Disponível https://contas.tcu.gov.br/etcu/ObterDocumentoSisdoc?seAbrirDocNoBrowser=true \&codArqCatalogado= 8639365, acesso em 24/04/2018. 
$388 \%$, ao passo que a inflação no período foi de $123 \% .{ }^{67}$ Neste período foram contratados 1.051 juízes federais e 13.000 novos servidores públicos. ${ }^{68}$ Uma nova expansão do sistema - que inevitavelmente se mostrará necessária caso mantido o atual modelo de resolução de disputas - elevará de forma ainda mais acentuada o gasto público com o sistema de justiça.

\section{Propostas de aprimoramento do sistema brasileiro}

Buscamos demonstrar que o atual modelo de resolução de conflitos previdenciários no Brasil apresenta dois problemas principais: a falta de independência do órgão incumbido da revisão administrativa e a ausência de garantias procedimentais que assegurem uma adjudicação administrativa justa. Essas deficiências parecem acarretar a falta de confiança no sistema de adjudicação administrativa, já que os reclamantes possivelmente não acreditam que seu conflito será resolvido de maneira justa e imparcial por um órgão que integra a própria Administração Pública e cujos membros não possuem garantias para agir com independência. Contudo, as reais causas dessa desconfiança não foram analisadas de forma empírica neste artigo e talvez esse seja um tema que mereça um estudo empírico mais aprofundado no futuro.

De todo modo, os efeitos de um sistema de adjudicação administrativa ineficaz são evidentes. Considerando que no Brasil não é necessário o exaurimento do sistema de revisão administrativa para que o conflito seja levado ao judiciário, e em razão da gratuidade de custas e da assistência judiciária concedida às pessoas carentes, a grande maioria dos casos não passa pelo Conselho de Recursos e vai diretamente para o sistema judicial, perdendo-se uma oportunidade de filtrar os erros da agência administrativa e de desafogar as cortes. Assim, a maioria dos conflitos previdenciários é judicializada e os juízes assumem uma função que extrapola aquela tradicionalmente reservada ao judiciário de controle da legalidade dos atos da Administração Pública.

Pensamos que os efeitos negativos apontados podem ser minorados através das seguintes medidas:

a) instituição de garantias aos membros do Conselho de Recursos para que

\footnotetext{
${ }^{67}$ Informação disponível em https://www3.bcb.gov.br/CALCIDADAO/publico/exibirFormCorrecaoValores.do?method=exibirFormC orrecaoValores, acesso em 16/03/2018

${ }^{68}$ Dados extraídos da comparação entre os Relatórios Justiça em Números do Conselho Nacional de Justiça, edições 20004 e 2014, disponíveis em http://www.cnj.jus.br/programas-e-acoes/pj-justica-emnumeros, acesso em 01/03/2018.
} 
possam atuar com independência e imparcialidade. Para isso, sugere-se que os membros sejam nomeados para um mandato fixo com termo de média ou longa duração e somente possam ser afastados por justa causa. O processo de nomeação deve exigir qualificação técnica para a função e conter provisões que evitem a interferência política na indicação dos candidatos. Esse modelo não é propriamente novo no direito brasileiro, uma vez que essa é a forma adotada para a nomeação dos dirigentes das agências regulatórias independentes;

b) previsão legal de garantias procedimentais que assegurem o devido processo legal na fase de revisão administrativa, concedendo-se ao reclamante o direito de audiência, na qual poderá apresentar provas, impugnar provas contrárias, indicar testemunhas e ser ouvido, exercendo plenamente o direito de ter as suas razões consideradas pelo adjudicador. Contudo, deve-se manter a preocupação para que as principais vantagens do sistema de adjudicação administrativa não desapareçam: a informalidade, a oralidade e a celeridade;

c) adoção de medidas que aumentem a transparência do sistema de adjudicação dos conflitos previdenciários e o conhecimento do sistema pelos interessados. A decisão inicial que nega um benefício previdenciário deve conter informação sobre a possibilidade de revisão da decisão por um órgão independente. As orientações sobre os procedimentos e prazos para recorrer devem estar disponíveis nas agências da previdência social e na internet, em linguagem clara e acessível. Deve haver funcionários preparados para assistir os reclamantes em seus recursos, preenchendo formulários e orientando-os na obtenção de documentos importantes. As audiências perante o Conselho podem ocorrer através de videoconferência, em agências da previdência social (que possuem grande capilaridade em todo o território nacional ${ }^{69}$ ), evitando-se grandes deslocamentos de pessoas com poucos recursos financeiros;

d) criação de um indicador da qualidade da decisão administrativa inicial, aferido pelo percentual de reforma destas decisões pelos órgãos de adjudicação administrativa ou pelo judiciário. Propõe-se que a parcela da remuneração dos servidores das agências referente à avaliação de desempenho seja calculada, dentre outros fatores, de acordo com esse indicador de qualidade, de modo que os servidores que tenham suas decisões mantidas em maior proporção sejam melhor remunerados.

\footnotetext{
${ }^{69}$ O Instituto Nacional do Seguro Social possui mais de 1.500 agências distribuídas em todos os Estados da federação.
} 
Desta forma, haverá incentivo para que as decisões iniciais sejam proferidas com qualidade desde a primeira vez e que estejam de acordo com a jurisprudência administrativa e judicial, diminuindo a quantidade de impugnações.

Acreditamos que essas medidas são capazes de gerar um progressivo aumento da confiança dos usuários no sistema de adjudicação administrativa. Na medida em que o sistema de adjudicação se mostrar efetivo, resolvendo conflitos com rapidez e independência, cada vez mais as pessoas buscarão utilizá-lo. Espera-se, também, uma redução da judicialização, pois os juízes tenderão a adotar uma postura mais deferente em relação às decisões proferidas por agentes especializados e independentes. Caso o juiz verifique ilegalidade ou falta de suporte probatório em determinado caso, pode determinar a sua devolução para que ele seja reanalisado pelo adjudicador, o que irá acarretar a redução da atividade probatória nas cortes de justiça.

\section{Conclusão}

$\mathrm{O}$ artigo buscou analisar meios alternativos para a resolução dos conflitos previdenciários no Brasil, em razão da constatação de que o modelo vigente, eminentemente judicial, não está mais correspondendo às expectativas de acesso à justiça daqueles que desejam contestar uma decisão administrativa que nega um benefício previdenciário.

Para atingir este objetivo, o artigo realizou uma análise comparativa dos sistemas de resolução de disputas previdenciárias adotados por alguns países da common law, a fim de identificar as semelhanças e as diferenças entre os sistemas e analisar as deficiências do modelo brasileiro.

Ao final, foram formuladas propostas de aprimoramento do sistema de adjudicação administrativa brasileiro, que buscam atacar os principais problemas encontrados: a falta de independência e de imparcialidade do órgão de revisão administrativa e a ausência de garantias procedimentais na fase administrativa.

Espera-se que essas sugestões contribuam para o estudo de meios alternativos de resolução de conflitos previdenciários, com especial ênfase na ampliação do acesso à justiça de setores menos favorecidos da população, buscando-se a composição justa e célere destes litígios e a redução da judicialização.

\section{REFERÊNCIAS}


ASIMOW, Michael. Five Models of Administrative Adjudication. American Journal of Comparative Law, 2015.

ASIMOW, Michael; LUBBERS, Jeffrey S..The Merits of "Merits" Review: A Comparative Look at the Australian Administrative Appeals Tribunal. Windsor Yearbook of Access to Justice, v. 28, n. 2, dez. 2010. Disponívelemhttps://ssrn.com/abstract=2782497, acesso em 29/11/2017.

BRITO, Thiago. Fundamentação das Decisões Judiciais: Elementos para Superação do Conceito de Motivação das Decisões a partir da Análise Comparativa da Atuação Jurisdicional da SupremeCourte dos Tribunais Brasileiros. Tese de Doutorado.

BRYDEN, Philip. A Canadian Perspective of Tribunal Independence. Melbourne: The Australasian Institute of Judicial Administration Incorporated, 2013. Disponível em http://www.coat.gov.au/images/downloads/tas/Tribunal\%20Independence.pdf, acesso em $27 / 06 / 2018$.

CANE, Peter. Administrative Tribunals and Adjudication. Oxford: Hart Publishing, 2010.

CAPPELLETTI, Mauro; GARTH, Bryant. Access to Justice and the Welfare State. Cappelletti, Mauro (Coord.). Florença: Le Monnier, 1981.

CAPPELLETTI, Mauro; GARTH, Bryant. Acesso à Justiça. Tradução de Ellen Gracie Northfleet. Porto Alegre: Fabris, 1988.

CAPPELLETTI, Mauro. Alternative Dispute Resolution Processes within the Framework of the World-Wide Access-to-Justice Movement. The Modern Law Review, v. 56, n. 3, mai. 1993.

CRAIG, Paul. Administrative Law, 5 ed .Londres: Sweet \& Maxwell, 2003.

ERKUIL, Paul R; LUBBERS, Jeffrey S.. Alternative Approaches to Judicial Review of Social Security. Disability Administrative Law Review, v . 55 , n. . 4, outono 2003.

GIFFORD, Daniel. Adjudication in Independent Tribunals: The Role of an

Alternative Agency Structure. In Notre Dame Law Review, 1990, v. 66.

HUSA, Jaakko. A New Introduction to Comparative Law. Portland: Hart Publishing, 2015.

O'CONNOR, Deirdre. Effective Administrative Review: An Analysis of Two-tier Review. Australian Journal of Administrative Law, v. 1, n. 1, nov. 1993.

ELLIS,Ronald. Unjust by Design: Canada's Administrative Justice System. Vancouver: UBC Press, 2013.

SEDLEY, Stephen. Lions Under the Throne: essays on the history of English public law. Cambridge: Cambridge University Press, 2015. 
SOSSIN, Lorne. Access to Administrative Justice and Other Worries. In: FLOOD, Colleen \& SOSSIN, Lorne (Org.). Administrative Law in Context, 2 ed. Toronto: Edmond Montgomery Publications, 2013.

STREET, Harry. Access to the Legal System and the Modern Welfare State: A European Report From the Standpoint of an Administrative Lawer. In Access to Justice and the Welfare State. Cappelletti, Mauro (Coord.). Florença: Le Monnier, 1981.

TENENBLAT, Fabio. Abuso no Acesso ao Judiciário: Custos Econômicos e Sociais. Dissertação de Mestrado.

Submetido em: 27/06/2018

Aceito em: 15/07/2018 